doi: $10.19090 /$ i.2021.32.233-244

UDC: $322(091)$

BORIS MILINKOVIĆ

Serbian Orthodox Church

milinkovicboris@live.com

\title{
THE RELATIONSHIP BETWEEN CHURCH AND STATE IN THE MEDIEVAL DOCUMENT DICTATUS PAPAE
}

\begin{abstract}
The Dictatus Papae is a key primary source for research into the history of Church reforms in the eleventh century, the leading figure of which was Pope Gregory VII Hildebrand. The document consists of twenty-seven statements defining the prerogatives of papal authority in other ecclesiastical and spiritual areas as well as in relationship to secular rulers under the pope's spiritual authority. This paper will examine some of these statements giving the pope religious and secular prerogatives regarding his authority over secular rulers. A detailed analysis of some of these statements and of historical literature related to the document will provide clear insight into how current historical scholarship views the document and will also showcase the document's concepts from a completely new perspective. Thus additional space will be opened up for a detailed analysis of the influence of this document on the development of the relationship between Church and state from the time it was written until the present day.
\end{abstract}

Keywords: Dictatus Papae, Church, state, authority, papal register.

\section{Introduction}

I n Serbian theology, medieval papal documents - especially those that emerged immediately after the Great Schism (1054) - and analyses of them are quite rare. For this reason, papal documents, and in particular those relating to the pope's spiritual and secular authority have remained unknown within this scholarly field. For this reason, as well as some objective ones, could also be due to a lack of interest; however, this lack of interest could also be the result of a lack of understanding in primarily Orthodox areas of southeastern Europe of the importance and influence that ideas contained in this type of document have. Therefore, the primary aim of this brief analysis of a crucial eleventh-century papal document is to approach this topic from a Serbian theological perspective and thus point to a specific understanding of the relationship between secular and spiritual authority in the West. This paper will analyze source texts from the papal register of Pope Gregory VII, which, in addition to the Dictatus Papae, also contains a considerable amount of correspondence between the pope and secular rulers, and will help create a clear understanding of the document and its role in creating what today represents the concept of the relationship between secular and spiritual authority in the West. 


\section{The Dictatus Papae}

Pope Gregory VII's Dictatus Papae is still known due to Pope Gregory VII's register, ${ }^{1}$ which has been preserved in its entirety. This document represents perhaps the most important content in the entire papal register, primarily because of its importance in the Gregorian Reforms. $^{2}$ There is considerable doubt regarding the authenticity of papal registry, but in academic circles it is mostly used as an authentic source on which to base studies of the history of Pope Gregory VII's papacy. ${ }^{3}$ Scholars have come to the conclusion that the register can be used as an authentic source due to years of work by a large number of historians. ${ }^{4}$

Aside from facts pointing to its authenticity, within the scope of their research, there are also many facts with a negative connotation regarding its authenticity. One of the biggest opponents of its authenticity is the very fact that a lot of information about events does not exist in the register, which in a way could be evidence of some sort of censorship or perhaps historical inaccuracies arising from the production of copies. An opponent of this opinion is Alexander Murray, who sees an explanation in the customs of that time. ${ }^{5}$ Very often the documents written by popes were incomplete because a written document was only an accompanying recommendation for someone who would later convey the message orally.

Of all that is known about this register, what leaves the most room for doubt regarding its authenticity is that, of all the papal registers from the eleventh century, only that of Pope Gregory VII is preserved. ${ }^{6}$ Apart from being the only surviving register, additional doubt regarding the originality of its content comes from the fact that the collection of letters preserved in the register, which are an important source of information about this period, was later added to the register. Such is the opinion of Herbert Cowdrey, who claims that, at that time, it was not common for correspondence to be registered. ${ }^{7}$ Nevertheless, an affirmative position regarding the authenticity of this historical source has prevailed, as well as one regarding the texts contained in it. Cowdrey himself contributes to its authenticity by citing three types of very important sources that were used for collecting information about the letters and for compiling the collection of Pope Gregory's letters in the register. ${ }^{8}$ Thus, when analyzing the Dictatus Papae, it is completely justifiable to hold the opinion that it is the authentic text of a document contained in an authentic collection such as Pope Gregory VII's register.

According to the Oxford Dictionary of Popes, which contains, among other things, a great deal of detail about the life of Pope Gregory VII, it cannot be determined with complete certainty when exactly the Dictatus Papae was created. ${ }^{9}$ Based on where it is in the register

\footnotetext{
This register of Pope Gregory VII's written correspondence is kept in the Vatican's archives. It is extremely valuable in terms of the relationship between secular and spiritual power, since it contains a large number of letters addressed to various secular rulers, in the first place to the German King Henry IV.

Milinković 2019: 238.

Whitney 1919: 132.

Oestreich 1921: 39.

Murray 1966: 153.

Cowdrey 2004: 61.

Cowdrey 1972: 24.

Ibid.

Kelly, Walsh 2009: 155.
} 
in which it was preserved, and if we accept that the documents were arranged in chronological order, it is possible to determine approximately when it was compiled. Due to this, the prevailing opinion places it before King Henry IV's repentance in Canossa and after one of the councils regularly held during Lent, most likely in $1075 .{ }^{10}$ Eamon Duffy holds a slightly different opinion, according to which the document is also connected to the year 1075, but that is the year indicated as being when the document was inserted into the register. ${ }^{11}$

The Dictatus Papae is not directly mentioned in the Regesta either, but throughout many events during the pontificate of Gregory VII mentioned by Jaffé, there are indirect references to the pope's ideas concerning the relationship between secular and spiritual authority. ${ }^{12}$ A particular problem for determining the document's exact date, and for its nature and role in general, is that there are no surviving references to it from Pope Gregory VII's contemporaries or from authors who lived and worked immediately after the pope's death. Regardless of whether these references were affirmative or not regarding the ideas of eleventh century Church reforms, more detailed study of the document itself is still not possible. However, the best proof of its authenticity without a doubt remains the fact that, throughout his pontificate, Pope Gregory VII himself fought for the implementation of the reforms in precisely the spirit of the ideas contained in the Dictatus Papae. ${ }^{13}$ Accordingly, Brian Tierney claims there is no doubt that the views expressed in this document are the product of Pope Gregory VII's opinion on the issues addressed in particular places within the document. ${ }^{14}$

\section{Thematic Structure of The Dictatus Papae}

The Dictatus Papae is composed of twenty-seven principles that deal with the prerogatives connected to the Holy See. All the principles of the document are separated from each other, but they do not always deal with different areas of papal action. Some of them are mutually connected, because they relate to the same areas in which the papal authority should apply its reformist views. In the chronology of the preceding events, Brian Tierney cites the pope's actions against Simony and Nicolaism, followed by lay investiture, as the reasons for this document. ${ }^{15}$ The creation of the document and its presence in the register is justified by the need to establish positions regarding the further implementation of basic reform. This may explain the principles in the document that strengthen papal authority and give greater authority to both the popes and to their legates when resolving issues within the Church. One of these is Principle III, ${ }^{16}$ and it envisions only the pope having the authority to depose or

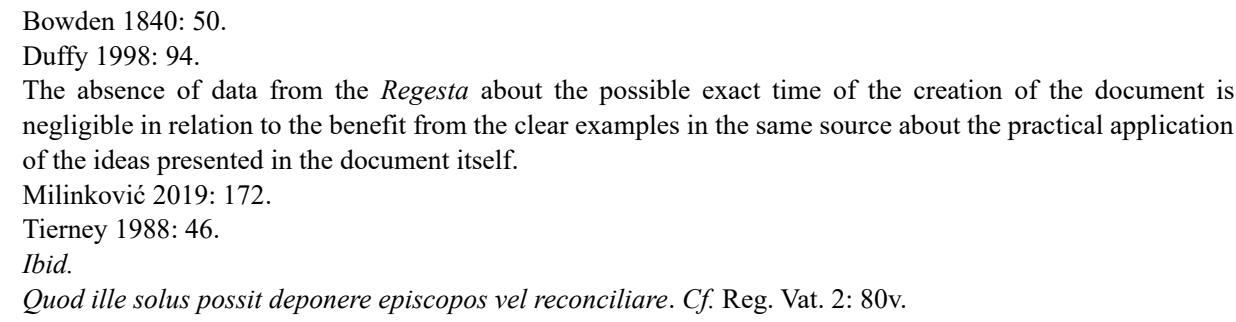


reinstate bishops ${ }^{17}$ In addition, Principle $\mathrm{V}^{18}$ envisions the pope also being able to depose a bishop who is not present at the Church assembly. The legate's authority to resolve internal Church disputes is defined in Principle IV, ${ }^{19}$ and the pope's inviolable right to impose new laws according to which Church units would be organized is defined in Principle VII. ${ }^{20}$

Furthermore, the intent of the some of the principles in this document is to alter the Church hierarchical order. One of these is Principle $\mathrm{XV},{ }^{21}$ which holds that ordination by the pope is considered more important than by other bishops. Even these parts of the document can in a way be considered intra-church. If it was thus possible to contribute to the further development of Church reforms to reduce secular influence and thus eradicate simony and Nicolaism, how can the existence of principles in this document in which the pope is given the right to influence secular governments be justified? Principles VIII, ${ }^{22} \mathrm{XII}^{23}$ and XXVII ${ }^{24}$ in the Dictatus Papae ${ }^{25}$ present viewpoints that have nothing to do with reducing secular influence, simony, and Nicolaism. Quite the contrary - these three principles indicate this involves an encroachment on secular governments' actions and influence. Principle VIII stipulates that only the pope can use imperial insignia, Principle XII that only he can depose secular rulers, and Principle XXVII that royal subjects can be absolved of their fealty to wicked men. ${ }^{26}$ Franjo Šanjek, who sees these three principles as exclusively elements of Pope Gregory VII's political actions, indirectly suggests there is no connection to implementing reforms in relation to Church life, and that this only concerns secular authority. ${ }^{27}$ But Šanjek is not so direct, and he mentions Pope Gregory's views in the Dictatus Papae as an attempt to expand papal influence into the realm of political issues. ${ }^{28}$

Some papal provisions collected in this document may have resulted from needing to determine the direction of Church reforms, but some elements contained in it seem to indicate that it had become an attempt to institute papal authority over that of the state. Such an understanding of Pope Gregory VII's ideas concerning papal power as defined in this document is based on a firm belief found in the document itself. In Principle XXIII ${ }^{29}$

17 Having in mind that the mentioned principle emphasizes the exclusive right of the Pope to appoint and remove bishops, this at the same time excludes the need for anyone's consent.

18 Quod absentes papa possit deponere., $C f$. Reg. Vat. 2: 80v.

19 Quod legatus eius omnibus episcopis presit in concilio etiam inferioris gradus et adversus eos sententiam depositionis possit dare., Ibid.

20 Quod illi soli licet pro temporis necessitate novas leges condere, novas plebes congregare, de canonica abbatiam facere et e contra, divitem episcopatum dividere et inopes unire., Ibid.

21 Quod ab illo ordinatus alii ecclesiae preesse potest, sed non militare; et quod ab aliquo episcopo non debet superiorem gradum accipere., Ibid.

22 Quod solus possit uti imperialibus insigniis. Ibid.

23 Quod illi liceat imperatores deponere. Ibid.

24 Quod a fidelitate iniquorum subiectos potest absolvere. Cf. Reg. Vat. 2: 81r.

25 Reg. Vat. 2: 80v.

26 If the Pope considers any secular ruler a sinner, this can be applied to him as well. Given the character of the Gregorian Reforms, it is very likely that this principle was primarily included in the document for that reason. Cf. Milinković, 238.

27 Šanjek 2008: 13.

28 Ibid.

29 Quod Romanus pontifex, si canonicae [sic] fuerit ordinatus, meritis beati Petri indubitanter efficitur sanctus testante sancto Ennodio Papiensi episcopo ei multis sanctis patribus faventibus, sicut in decretis beati Symachi 
specifically, the pope expresses the belief that every Roman pontiff, if canonically ordained, is indisputably sanctified by the merits of St. Peter. If this principle is analyzed together with Principle XXII, ${ }^{30}$ in which Pope Gregory VII expresses the belief that the Roman Church has never erred nor will ever err in the future, a conclusion can be made that his goal was to explain the infallibility of the Roman Church through the sanctity of all successors to St. Peter. ${ }^{31}$

Based on these facts, Uta-Renate Blumenthal concludes that it is not at all surprising that Pope Gregory believed he had the right to both spiritual and secular powers. ${ }^{32} \mathrm{He}$ believed papal service was the implementation of a divine mission which only the pope, as the successor to Apostle Peter, could carry out, because he was the only one who could not fall under demonic influence and err. Such a conviction and the adoption of a papal document on the basis of which he wanted to lead reforms, indicate that Pope Gregory turned the reform struggle into a conflict exclusively over establishing of the relations between secular and spiritual authorities. The focus of the reforms was no longer to resolve issues of simony, Nicolaism, and secular investiture, but to prove the supremacy of the pope's spiritual authority over the secular authority of the German king.

Based on this part of the role of the Dictatus Papae in implementing Church reforms, several influences on the development of some of its elements begin to emerge. The historian José Orlandis discusses this when he points to the influence he sees from ideas presented in the Donatio Constantini (Donation of Constantine) regarding their origin and formulation in some points of the document. ${ }^{33}$ According to this document, which was found in the fifteenth century to be a forgery, ${ }^{34}$ secular authority over the Western world had been given to the pope by Emperor Constantine the Great and thus could not be questioned. Orlandis supports this connection by stating that Donatio Constantini itself was very popular at the time, and that its credibility was not at all in doubt. Without a doubt, by touching on various areas of Church reform, as a papal document the Dictatus Papae, played a clear role in affirming previous positions regarding papal reform and justifying papal reform, which until then had been uncommon.

One of the pope's positions that had been unusual up until then concerned the papal legates' role and authority in Church reform and their powers. As was previously mentioned, Principle IV stipulates that papal legates have the right of priority at all Church councils, even if they are of a lower rank than all others present. As papal deputies, they can use all the prerogatives of papal authority, and can even depose bishops. It would seem, when analyzing the transfer of authority to the papal legates, that papal power and authority would be diminished by this. However, the actual outcome indicates that the opposite was achieved. In

pape continetur. $C f$. Reg. Vat. 2: 80v.

Quod Romana ecclesia nunquam erravit nec imperpetuum scriptura testante errabit. Ibid.

31 Also in accordance with the spirit of Gregorian Reforms, it is no coincidence that these two principles in the document come one after the other, and that Pope Gregory VII wanted to say that, from everything stated in these two points, it would follow that the Roman pontiff, as the head of the Roman Catholic Church and the source of its infallibility, is therefore himself infallible.

32 Blumenthal 1988: 118.

33 Orlandis 2004: 79.

34 Popović 2007: 154. 
foreseeing such broad powers for papal legates, Pope Gregory VII in fact wanted to strengthen papal influence. Having them present in several places at the same time and with the same powers as he himself had would only increase his influence. ${ }^{35}$ Pope Gregory VII's decision to confer such broad powers to papal legates was also influenced by the personal experience he had gained as a papal legate during Leo IX's papacy, when he played an important role several times as a papal legate in implementing reforms. ${ }^{36}$ Kriston Rennie believes that, in light of implementing reforms outside Italy's borders, such a move by the pope makes sense because it was necessary to create a critical mass of reformists there in order to more easily implement reform policy. ${ }^{37} \mathrm{He}$ believes that this move was provoked by a complete lack of justice, which would be compensated for by the presence of direct papal representatives in cases involving Church law. The very fact that the role and authority of papal legates was included in a papal document, which he planned to use when directing Church reforms, reveals how serious his intention was for Church reforms to be all-encompassing.

Opinions differ concerning the role of the papal document as a starting point for directing Church reforms. The historian Hubert Jedin believes that by compiling the Dictatus Papae, which was meant to be reminiscent of earlier legal and ecclesiastical collections, the pope wanted his papacy to achieve a continuation of Church tradition. ${ }^{38}$ Based on this, in the document itself he did not see his goal as being to implement Church reforms. Rather he believed that its purpose was to establish papal primacy, which could be employed if necessary. Jedin presents his assessment of the source and structure of the document in order to further diminish the role of the document in reform, while also emphasizing the pope's intention to establish papal primacy. ${ }^{39} \mathrm{He}$ emphasizes that there is an apparent absence in the document of any systematic work, and that another false document, the Pseudo-Isidorian Decretals, was also used as evidence of papal primacy. Regardless of whether the Dictatus Papae was meant to be a means to either direct or assist reform by providing evidence for papal primacy, its role in implementing reform cannot be overlooked. If papal primacy was meant to bolster influence and facilitate the implementation of reforms, then the difference between these two views on the document's role is negligible. Pope Gregory VII's act, which referred to the fact that the Roman Catholic Church had never erred in the past and therefore never would err in the future, ${ }^{40}$ suggests it was meant to establish papal primacy for the sake of secular and spiritual supremacy, rather than provide evidence for the Roman pontiffs' personal sanctity. ${ }^{41}$

One additional detail on which the understanding of the role of the Dictatus Papae in eleventh century Church reform depends is properly understanding document's structure. If the form of the document preserved in the Pope Gregory VII's register is complete, it is

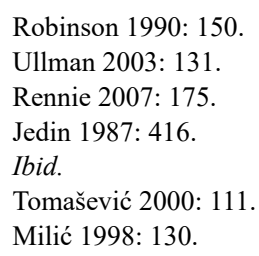


difficult to view it as one of the canonical compilations whose tradition it was meant to uphold. In scholarly works, the document is mostly seen as headings drawn up for the purpose of writing a new compilation of canons meant to secure papal influence in secular and spiritual matters. ${ }^{42}$ Šanjek believes this is unquestionably the document's structure; however, he disagrees that Pope Gregory VII was not able to complete this possible compilation. ${ }^{43} \mathrm{He}$ believes this collection has been lost rather than left unfinished. One of the principles in the document further supports these being headings of canons. Although it is disputed that the pope permitted changes to the canons, usually by attributing them to his close associates, ${ }^{44}$ they were still the result of his ideas and influence. There is evidence of this in Principles VII ${ }^{45}$ and XVII, ${ }^{46}$ which specify that only the pope can create new canons and determine how they should be applied. The rights the document gave to the to the pope by themselves confirm that a project as important for the papacy as the Dictatus Papae certainly represented much more than the ideas and goals of reform it enumerates.

Another related juridical dimension of the Dictatus Papae becomes clear when it is viewed as having an ecclesiastical and canonical role in Church reform. This dimension emerged as a result of the document's ecclesiastical and canonical nature, which is why it becomes clear only in that light. The document's juridical nature and others like it is of interest due to later developments that were directly or indirectly related to the origin or realization of the ideas contained within it. Until then, it could not have been recognized when studying the circumstances related to the document itself or the topics to which it referred. For this reason, there is no commentary on the document's juridical nature from its contemporaries. This remained unchanged even long after the document was created. Only by viewing it from a modern perspective, which is a product of later influences on the creation of the juridical nature of ecclesiastical and canonical collections, and which influenced the development of relations between the Church and the state, does the legal significance of this document become clear.

Robert Sommerville believes that the Dictatus Papae, and more specifically Principle XVI ${ }^{47}$ gave legitimacy to all decisions made at the regular annual councils convened by Pope Gregory VII. ${ }^{48}$ Principle XVI deals with the pope's absolute right to make a decision about the nature of the council on which the implementation of individual councils' decisions directly depended. Thus, Pope Gregory VII most likely wanted to give legitimacy to certain conciliar decisions that he believed were important for Church reform. Jean Louis Ska says that the emergence of the Dictatus Papae and its role in Gregorian reform represent the first great revolution in history. ${ }^{49} \mathrm{He}$ cites the results of his analyses,

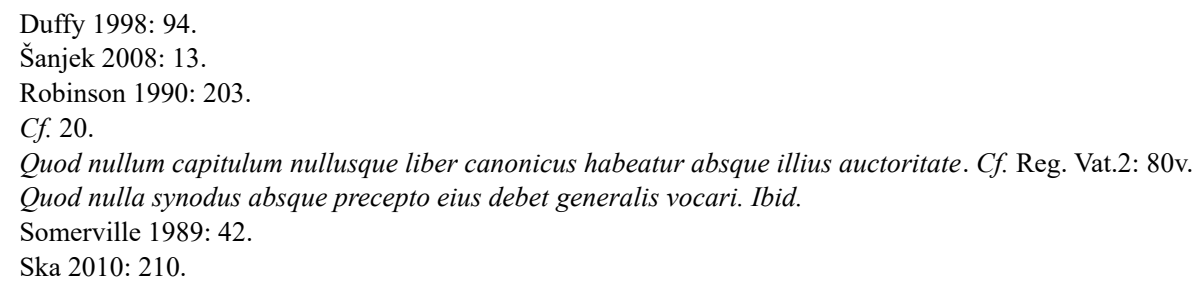


which found that the first modern legal system in the West emerged during Gregory VII papacy as a result of these reforms, which were meant to allow the Church to legally function independently from the influence of secular authorities. ${ }^{50}$ Ska believes that what is revolutionary about this document is that by entering into force, the foundations were laid for a concept that later became known as the Rechtsstaat. According to him, this was achieved by Pope Gregory VII who used a legal document as the authoritative bedrock on which he based the organization of the Church and the state. This was a significant shift from the existing principle, according to which authority was based on a power that was a means to fulfill the will of a secular or spiritual ruler. ${ }^{51} \mathrm{He}$ concludes his analysis by stating that it was somewhat paradoxical that the first example of the what could be considered a Rechtsstaat came into being within an ecclesiastical state. All later examples of states that fought for the rule of law struggled against the Church because they considered it a direct opponent of the rule of law, even though in their legal documents they included legal provisions that in most cases originated from canonical collections. ${ }^{52}$

Although the historical information Ska refers to when he states that a legal document was the basis for Church and state governance is indisputable, there are different views and principles regarding the role of legal documents in Church organization in the West. Gustav Radbruch points out that, in Roman Catholic Church practice, there is an understanding of the relationship between law and spiritual teaching that poses a danger to properly understanding the role of ecclesiastical law in the Church. ${ }^{53}$ Basing his position on the Orthodox understanding expressed by Dostoevsky in the story The Grand Inquisitor ${ }^{54}$ Radbruch claims that in Roman Catholicism the legal Church and the spiritual Church have always been equal. For Roman Catholics, the Church in the legal sense and the Church in the spiritual sense are the same. Viewed in this light, the role of the Dictatus Papae in Church reforms becomes something completely different from what Ska holds.

\section{Primary Ideas in The Dictatus Papae}

What helps in fully understanding this document and clearly seeing its place within eleventh century Church reform, as well as what the primary topics in the document are, is the character of its author, ${ }^{55}$ which is to some extent visible in his work. No historical source or any of the literature concerning this issue expresses doubt that Pope Gregory VII created the Dictatus Papae. Because of this, the author's personal influence can be found in the document and his actions related to it can be analyzed. By considering the principles within the document and the tone in which they are presented, the content of the document appears to indicate that they really are an expression of an uncompromising view that condemns in advance anyone who does not follow it. ${ }^{56}$ This is most visible in the positions that were

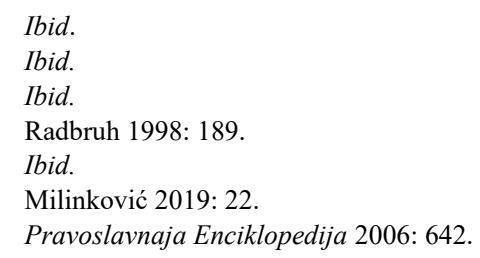


considered to be the most radical. The radicalism of these views can be recognized only after creating a unique image of Pope Gregory VII's viewpoints and ideas. No matter how radical some of Pope Gregory VII's views and ideas presented in this document were, what led to the radicalization of his views cannot be ignored. The adoption of this document, as well as its structure and character, were certainly provoked, among other things, by the actions of King Henry IV of Germany in connection to the relationship toward spiritual authority in general and to the Holy See in particular. The best evidence for the document being created as the result of actions that disrupted relations between the Holy See and the German crown is that the pope defined his later relationship with the king precisely on the basis of the provisions set out in the Dictatus Papae. Therefore, the very emergence and structure of the document can to some extent be seen as a sort of defense mechanism for the Holy See against the German court.

Therefore, for a full understanding of the Dictatus Papae and its role in reforms, it is important to recognize the direction in which Pope Gregory VII's ideas of Church reforms was headed. The document itself and its basic provisions best help define this direction. Despite some of the provisions being more or less in line with Church practice, most of them did not first appear in Pope Gregory VII's document. Joseph Lynch notes that the Dictatus Papae, as a complete reform project, presents a set of ideas that did not even exist at the beginning of the eleventh century. During the eleventh century they were simply a concept, and by the beginning of the thirteenth century they had been implemented to a considerable extent. ${ }^{57}$ Eamon Duffy says that many ideas based on the theory of papal primacy and infallibility, which were presented in an expanded form in Gregory VII's document, were well known in the Christian West even before the appearance of the papal document. ${ }^{58}$ This leads to the conclusion that the only idea that appeared in the document for the first time and that represents a turning point in relations between Church and state, is the idea that the pope can depose any secular ruler. Such an interpretation of papal authority until then had been completely unknown. The papal role in the selection of secular rulers was known, ${ }^{59}$ but such broad papal authority allowing him to depose a secular ruler by his own decision and to free his subjects of their oaths to the ruler was a complete novelty.

Along with a new standpoint regarding the pope's role in deposing and instating rulers, due to the emergence of this idea, there is a very clear indicator of the general nature and purpose of the Dictatus Papae. The initial theory that the Roman pontiff could depose any secular ruler leads to the final hypothesis that best explains the nature of the document in all its principles. This final hypothesis comes down to the fact that the Pope of Rome can pass judgment on anyone and in every area of spiritual and secular life, while at the same time no one can pass judgment on him. Because this concept was something completely unknown until then, there is a clear indicator of the primary ideas presented in this document, and thereby the ideas of its author. In addition to recognizing the primary ideas within the Dictatus Papae, this is the key to understanding its nature, purpose, and its role within Gregorian reform.

\section{Linč 1999: 192}

Duffy 1998: 95.

Ullman 1959: 230. 


\section{Conclusion}

Based on everything mentioned here, it can be concluded that by analyzing the Dictatus Papae and considering the relationship between the Church and the state in the thought and work of its author, Pope Gregory VII, the emphasis the document's ideas and aim and of the entirety of papal reform placed on the establishment of a universal theocratic monarchy becomes clear. A consideration of all the principles in the document and how they were put into practice by Pope Gregory VII indicates that the concept behind this document was such that, by implementing each of its principles, a strengthening of absolute papal authority in both spiritual and secular spheres would be ensured. Each of the previously mentioned hypotheses related to the origin and purpose of this document, which we have been analyzed here, cannot be confirmed in most principles of this document. The only common idea behind all the principles in the Dictatus Papae is that of creating a universal theocratic monarchy headed by the Roman pontiff. This fact clearly shows the relationship between the Church and the state from the perspective of this medieval papal document.

\section{REFERENCES:}

Blumenthal, U. R. The Investiture controversy; Church and Monarchy from the Ninth to the Twelfth Century, Philadelphia: University of Pennsylvania Press, 1988.

Bowden, J. W. The Life and Pontificate of Gregory the Seventh, II, London: Rivington, 1840.

Cowdrey, H. E. J. 'Pope Gregory VII (1073-85) and the liturgy', Journal of theological studies, 55, $1,2004,55-83$.

Cowdrey, H. E. J. The Epistolae vagantes of pope Gregory VII, New York: Oxford University Press, 1972. Duffy, E. Sveci i grešnici-povijest papa, Rijeka: Otokar Keršovani, 1998.

Jedin, H. Velika povijest Crkve, III Zagreb: Kršćanska sadašnjost, 1987.

Kelly, J. N. D. and Walsh, M. Oxford Dictionary of Popes, New York: Oxford University Press, 2009.

Linč, Dž. Istorija srednjevekovne crkve, Beograd: Klio, 1999. (Serbian Cyrillic)

Milić, M. Pape: od Sv.Petra do Ivana Pavla II, Split: Laus, 1998.

Milinković, B. Papska država u vrijeme Hildebranda, Beograd: Filip Višnjić, 2019. (Serbian Cyrillic) Murray, A. 'Pope Gregory VII and his letters', Traditio, 22, 1966, 149-202.

Oestreich, T. 'The Personality and Character of Gregory VII in Recent Historical Research', The Catholic Historical Review, 7, 1, 1921, 35-43.

Orlandis, J. Povijest kršćanstva, Split: Verbum, 2004.

Popović, R. Pojmovnik crkvene istorije, Beograd, 2007. (Serbian Cyrillic)

Pravoslavnaja Enciklopedija, Grigorij VII, www.pravenc.ru XII, 2006, 641-645. (22.08.2015) (Russian Cyrillic)

Radbruh, G. Filozofija prava, Beograd: Pravni fakultet Univerziteta, 1998. (Serbian Cyrillic)

Registra Vaticana 2, Gregorius VII (1073-1085), Archivio Segreto Vaticano (Reg. Vat 2)

Rennie, K. R. 'Uproot and destroy, build and plant, legatine authority under Pope Gregory VII', Journal of medieval history, 33, 2, 2007, 166-180.

Robinson, I. S. The Papacy 1073-1198, continuity and innovation, New York: Cambridge University Press, 1990.

Šanjek, F. 'Uloga Papinstva u afirmaciji Hrvatske u ranom srednjem vijeku (7-12 st.)' Problemi 
sjevernog Jadrana 9, 2008, 7-25.

Ska, J. L. 'Biblijsko pravo i zapadna demokracija', Služba božija, 50, 2, 2010, 209 - 222.

Somerville, R. 'The Councils of Gregory VII', in: A. M. Stickler, O. Capitani, H. Fuhrmann, M.

Maccorrone, R. Schieffer and R. Volpini (eds), Studi Gregoriani XIII, Roma: LAS, 1989, 33-53.

Tierney, B. The crisis of church and state. 1050-1300, Toronto: University of Toronto Press, 1988.

Tomašević, S. Pape kroz povijest, Rijeka: Adamić, 2000.

Ullman, W. 'Romanus Pontifex indubitanter efficitur sanctus: Dictatus Papae 23 in retrospect and prospec', in: G. B. Borino (ed), Studi Gregoriani VI, Roma: Abbazia di San Paolo, 1959, 229-264. . A Short History of the Papacy in the Middle Ages, Abingdon: Routledge, 2003.

Whitney, J. P. 'Gregory VII', The English Historical Review, 34, 134, 1919, 129-151. 


\title{
БОРИС МИЛИНКОВИЋ
}

Српска Православна Црква

\section{ОДНОС ЦРКВЕ И ДРЖАВЕ КРОЗ ПРИЗМУ СРЕДЫОВИЈЕКОВНОГ ДОКУМЕНТА DICTATUS PAPAE}

\begin{abstract}
Резиме
Документ Dictatus Papae представља кључни историјски извор прве категорије у проучавању историје црквених реформи у XI вијеку у којима је централна личност папа Григорије VII Хилдебранд. Структура документа је таква да се састоји од двадесет и седам тачака које дефинишу прерогативе папске власти, како у односу на друге црквене области у духовној сфери, тако и у односу на световне владаре који се у духовном смислу налазе под утицајем римског папе. У том контексту посебан осврт и акценат стављен је на чињеницу постојања појединих тачака документа која римском папи у односу на световне владаре дају прерогативе власти не само духовне, већ и световне природе. Детаљна анализа самог текста појединих тачака као и одговарајућа историјска литература дају јасан увид постојећег односа историјске науке према документу и исто тако истичу из потпуно нове перспективе примарне идеје самог документа. На тај начин створен је додатни простор за детаљне анализе утицаја овог документа на развој односа између Цркве и државе од његове појаве па све до данашњих дана. На основу свега реченог, долазимо до закључка да кроз призму документа Dictatus papae, а по питању односа између Цркве и државе у мисли и дјелу папе Григорија VII, као аутора овог документа, видимо јасно наглашену идеју и циљ како самог документа, тако и цјелокупног папиног реформског рада, о успостављању универзалне теократске монархије. Сагледавање свих тачака документа и чињеница њиховог остварења у дјеловању папе Григорија VII, указује нам на то да је концепција овог документа постављена на такав начин да спровођење сваке његове тачке осигурава учвршћивање апсолутне папске власти и у духовној и у световној сфери. Свака од раније наведених претпоставки везаних за настанак и циљ овог документа, а које смо претходно анализирали, не може наћи своју потврду у већини тачака овог документа. Једина заједничка идеја свих тачака документа Dictatus Рарае јесте идеја остварења универзалне теократске монархије са римским папом на челу. Ова чињеница јасно приказује какав је однос Цркве и државе у перспективи овог средњовијековног папског документа.
\end{abstract}

Кључне речи: Dictatus papae, Црква, држава, власт, папски регистар. 